\title{
PENGARUH AKTIVITAS DAN MOTIVASI BELAJAR TERHADAP PEIMBENTUKAN KARAKTER RELIGIUS PESERTA DIDIK DI SIMA NEGERI 7 MAKASSAR
}

\author{
Saina Pulukadang, Muzakkir, Misykat Malik Ibrahim \\ Pascasarjana UIN Alauddin Makassar, \\ Fakultas Tarbiyah dan Keguruan UIN Alauddin Makassar \\ Email: inazulziddan@gmail.com, muzakkir.ftk@uin.alauddin.ac.id, \\ misykat.mmi@uin-alauddin.ac.id
}

\begin{abstract}
The effect of activity and learning motivation on the formation of the religious character of students in Makassar 7 Public High School is intended to increase the learning activeness and learning motivation of students in the subjects of Islamic Education to form the relativistic character of students. This type of research is ex post facto using a quantitative approach. The population amounted to 944, a sample of 94 students, using the Proportionate Stratified Random Sampling technique. The research instruments were questionnaires, documentation, and observation. The data obtained were analyzed using descriptive and inferential statistics, namely simple and multiple linear regression analysis techniques. The results of this study gave the conclusion that the learning activities of students influence the formation of the religious character of students. This can be seen from the results of the analysis, namely the value of the calculated $t$ variable X1 is greater than the value of the t table $(10,233>2,364)$ with a significant level below 0.05 which is 0,000 . The results of the analysis of the value of the calculated $t$ variable X2 are greater than the value of the table $(21,776>2,364)$ with a significant level below 0.05 which is 0,000. Significant $F$ value of 0,000 (<0.05), the hypothesis is accepted.
\end{abstract}

Keywords: Activity, Learning Motivation, Formation of Religious Characters

\section{PENDAHULUAN}

\section{A. Latar Belakang}

$\mathrm{P}$

endidikan adalah upaya membina jasmani dan rohani manusia dengan segenap potensi yang ada pada keduanya secara seimbang sehingga dapat di lahirkan manusia seutuhnya. ${ }^{1}$ Pendidikan yang hanya menekankan segi pengetahuan, akan mengakibatkan anak didik tidak dapat berkembang menjadi manusia yang utuh. Akibatnya terjadi macam-macam tindakan yang tidak baik seperti yang akhirakhir ini terrjadi: tawuran, perang, ketidak adilan, menyontek dan lain- lain. ${ }^{2}$ Pendidikan adalah proses untuk memberikan manusia berbagai macam situasi yang bertujuan memberdayakan diri. Aspek-aspek yang di pertimbangkan antara lain: Penyadaran,

${ }^{1}$ Abudin Nata, Perpektif Islam Tentang Strategi Pembelajaran, (Jakarta: Kencana Media Group, 2009), h. 47.

${ }^{2}$ Paul Suparno, Reformasi Pendidikan (Yogyakarta: Kanisius, 2002), h. 13. 
pencerahan, pemberdayaan, perubahan perilaku. ${ }^{3}$ Proses pendidikan merupakan suatu sistem yang terdiri dari input, proses dan output. Input merupakan peserta didik yang akan melaksanakan aktivitas belajar, proses merupakan kegiatan dari pembelajaran sedangkan output merupakan hasil dari proses yang dilaksanakan.

Pendidikan yang baik dapat menghasilkan SDM yang berkemampuan untuk senantiasa meningkatkan kualitasnya secara terus menerus dan berkesinambungan sesuai dengan kemajuan dan tuntutan zaman.

Sebagaimana tercantum dalam Undang-Undang Republik Indonesia No. 20 tahun 2003 Bab II Pasal 3 yang berbunyi:

Pendidikan nasional berfungsi mengembangkan kemampuan dan membentuk watak serta peradaban bangsa yang bermartabat dalam rangka mencerdaskan kehidupan bangsa, bertujuan untuk berkembangnya potensi peserta didik agar menjadi manusia yang beriman dan bertakwa kepada Tuhan Yang Maha Esa, berakhlak mulia, sehat, berilmu, cakap, kreatif, mandiri, dan menjadi warga negara yang demokratis serta bertanggung jawab. ${ }^{4}$

Berdasarkan UU RI NO.20 Tahun 2003 di atas, diantara tujuan pendidikan nasional adalah mengembangkan potensi peserta didik dan membentuk manusia yang beriman dan berakhlakul karimah. Tentunya mengembangkan potensi melalui pembelajaran tentunya bagaimana upaya guru dan terkhusus peserta didik bisa merealisasikan pembelajaran yang aktif sehingga peserta didik penuh semangat untuk belajar dan hasil dari pembelajaran bisa mengarahkan peserta didik hidup berprilaku yang baik dari segi IPTEK dan IMTAQ.

\section{B. Kajian Teoritis}

\section{Aktivitas Belajar}

Aktivitas berarti kegiatan, keaktifan; giat/tidaknya. ${ }^{5}$ Belajar adalah berubah. Dalam hal ini yang dimaksudkan belajar berarti usaha mengubah tingkah laku. ${ }^{6}$ Jadi jika dihubungkan aktivitas belajar adalah kegiatan dengan giat mengubah tingkah laku seseorang (peserta didik). Perubahan dalam belajar tidak hanya berkaitan dengan penambahan ilmu pengetahuan, tetapi juga berbentuk kecakapan, keterampilan, sikap, pengertian, harga diri, minat, watak, penyesuaian diri. Jelasnya menyangkut segala aspek organisme dan tingkah laku pribadi seseorang.

Menurut perpektif keagamaan pun (dalam hal ini Islam), belajar merupakan kewajiban bagi setiap muslim dalam rangkah memperolehilmu pengetahuan sehingga derajat kehidupannya meningkat. Hal ini dinyatakan dalam surah Mujadalah:11 yang artinya: ... niscaya Allah akan meninggikan beberapa derajat kepada orang-orang

\footnotetext{
${ }^{3}$ Nurani Soyomukti, Teori-Teori Pendidikan (Yogyakarta: Ar-ruzz Media, 2010), h. 27.

${ }^{4}$ Undang-Undang RI No. 20 Tahun 2003, Sistem Pendidikan Nasional, (Jakarta: Sinar Grafika, 2008), h. 7

${ }^{5}$ Pius A. Partanto dan M. Dahlan al Barry, Kamus Ilmiah Populer (Surabaya: Arkola, 1994), h. 17.

${ }^{6}$ Sardiman A.M., Inrteraksi dan Motivasi Belajar Mengajar, Ed. I (Cet. XXI; Jakarta: Raja Grafindo Persada, 2012), h. 21.
} 
beriman dan "berilmu" ilmu dalam hal ini tentu saja harus berupa pengetahuan yang relevan dengan tuntutan zaman dan bermanfaat bagi kehidupan orang banyak. ${ }^{7}$

\section{Jenis-Jenis Aktivitas}

Para ahli mencoba mengadakan klasifikasi, antara lain Paul D. Dierich dalam Oemar Hamalik membagi kegiatan belajar menjadi 8 kelompok yaitu:

a. Kegiatan-kegiatan visual: membaca, melihat gambar-gambar, mengamati eksperimen, demonstrasi, pameran, mengamati orang lain bekerja, atau bermain.

b. Kegiatan-kegiatan lisan (oral): mengemukakan suatu fakta atau prinsip, menghubungkan suatu kejadian, mengajukan pertanyaan, memberi saran, mengemukakan pendapat, berwawancara, diskusi.

c. Kegiatan-kegiatan mendengarkan: mendengarkan penyajian bahan, mendengarkan percakapan atau diskusi kelompok, mendengarkan suatu permainan instrument musik, mendengarkan siaran radio.

d. Kegiatan-kegiatan menulis: menulis cerita, menulis laporan, memeriksa karangan, bahan-bahan kopi, membuat sketsa, atau rangkuman, mengerjakan tes, mengisi angket.

e. Kegiatan-kegiatan menggambar: menggambar, membuat grafik diagram, peta, pola.

f. Kegiatan-kegiatan metrik: melakukan percobaan, memilih alat-alat, melaksanakan pameran, membuat model, menyelenggarakan permainan (simulasi), menari, berkebun.

g. Kegiatan-kegiatan mental: merenungkan, mengingat, memecahkan masalah, menganalisis faktor-faktor, menemukan hubungan-hubungan, membuat keputusan.

h. Kegiatan-kegiatan emosional: minat, membedakan, berani, tenang, dan sebagainya. Kegiatan-kegiatan dalam kelompok ini terdapat pada semua kegiatan tersebut di atas, dan bersifat tumpang tindih. ${ }^{8}$

\section{Motivasi Belajar}

Motivasi adalah daya penggerak/pendorong untuk melakukan sesuatu pekerjaan, yang bisa berasal dari dalam diri dan juga dari luar. Sedangkan Purwanto, mengemukakan bahwa motivasi adalah suatu pernyataan yang kompleks di dalam suatu organisme yang mengarahkan tingkah laku terhadap suatu tujuan (goal) atau perangsang (incentive). Tujuannya adalah membatasi/menentukan tingkah laku organisme itu, dengan demikian motivasi dalam proses pembelajaran sangat dibutuhkan untuk terjadinya percepatan dalam mencapai tujuan pendidikan dan pembelajaran secara khusus. ${ }^{9}$

Motivasi belajar yang dikemukakan oleh Sardiman adalah keseluruhan daya penggerak di dalam diri peserta didik yang menimbulkan kegiatan belajar, yang

${ }^{7}$ Syah Muhibbin, Psikologi Pendidikan Dengan Pendekatan Baru, (Bandung: Remaja Rosdakarya, 2013), h. 94.

${ }^{8}$ Oemar Hamalik, Kurikulum dan Pembelajaran, (Cet. XV; Jakarta: Bumi Aksara, 2015), h. 90-91.

${ }^{9}$ Dalyono, M. Psikologi Pendidikan (Jakarta: Rineka Cipta. 2005), h. 6. 
menjamin kelangsungan dari kegiatan belajar, dan yang memberikan arah pada kegiatan belajar, sehingga tujuan yang dikehendaki oleh subjek belajar itu dapat tercapai. ${ }^{10}$

\section{Jenis-Jenis Motivasi}

Ada dua jenis motivasi dalam belajar dari dua sudut pandang yaitu motivasi yang berasal dari dalam diri pribadi seseorang yang disebut "motivasi intrinsik" dan motivasi yang berasal dari luar diri seseorang yang disebut "motivasi ekstrinsik" yakni sebagai berikut:

a. Motivasi Intrinsik

Menurut Winkel, motivasi timbul dari dalam diri seseorang tanpa bantuan orang lain. Sedangkan menurut Syaiful Djamarah motivasi intrinsik adalah motif-motif yang menjadi aktif atau berfungsinya tidak perlu dirangsang.

Berdasarkan pendapat di atas dapat disimpulkan bahwa motivasi yang timbul dari dalam diri seseorang tanpa rangsangan dari luar. Motivasi intrinsik adalah motif-motif yang menjadi aktif, atau berfungsi tidak perlu dirangsang dari luar, karena dalam diri setiap individu sudah ada dorongan untuk melakukan sesuatu. ${ }^{11}$

\section{b. Motivasi Ekstrinsik}

Motivasi ekstrinsik adalah motif-motif yang aktif dan berfungsinya karena adanya perangsang dari luar. Motivasi ekstrinsik dikatakan demikian karena tujuan utama individu melakukan kegiatan adalah untuk mencapai tujuan yang terletak di luar perbuatan yang dilakukannya. ${ }^{12}$

Hal-hal yang dapat mendorong motivasi ekstrinsik seseorang adalah apabila seseorang belajar dengan tujuan mendapat angka yang baik, naik kelas, mendapat ijazah, untuk mencari penghargaan berupa angka, hadiah dan lainnya.

\section{Pembentukan Karakter Religius}

Pendidikan merupakan bimbingan guru, ataupun dilakukan oleh alam dan lingkungan. Ahmad Tafsir dalam HM. Suyudi mendefinisikan pendidikan secara luas, yaitu "pengembangan pribadi dalam semua aspeknya", dengan catatan yang dimaksud "pengembangan diri". Mencakup pendidikan oleh diri sendiri, lingkungan dan orang lain. Sementara frasa "semua aspek" mencakup aspek jasmani, akal, dan hati. ${ }^{13}$ Dengan demikian, tugas pendidikan bukan sekedar meningkatkan kecerdasan intelektual, melainkan pula mengembangkan aspek kepribadian.

Karakter menurut istilah yunani, character dari kata charassein yang berarti membuat tajam atau membuat dalam. ${ }^{14}$ Hal yang sama diuraikan Lorens Bagus yang mendefinisikan karakter sebagai nama dari jumlah seluruh ciri pribadi yang mencakup

\footnotetext{
${ }^{10}$ Sardiman, A. M. Interaksi dan Motivasi Belajar-Mengajar. Jakarta: Rajawali Press. 2010, h, 75.

${ }^{11}$ Sardiman A.M, Interaksi \& Motivasi Belajar Mengajar, 2010, h, 73

12 Sardiman A.M, Interaksi \& Motivasi Belajar Mengajar, 2010, h, 91

${ }^{13}$ HM. Suyudi, Pendidikan Dalam Perspektif Al-Qur'an: Integrasi Epistimologi Bayani, Burhani, dan Irfani (Yogyakarta: MIKRAJ, 2005), h. 52.

${ }^{14}$ Lorens Bagus, Kamus Filsafat (Jakarta: Gramedia, 2005), h. 392.
} 
prilaku, kebiasaan, kesukaan, ketidak sukaan, kemampuan, kecenderungan, potensi nilainilai, dan pola-pola pemikiran. Atau, menurutnya suatu kerangka kepribadian yang relatif mapan yang memungkinkan ciri-ciri semacam ini mewujudkan dirinya. ${ }^{15}$

Karakter mengacu pada serangkaian sikap (attitudes), prilaku (behaviors), motivasi (motivasions), dan keterampilan (skills). Karakter menurut Zubaedi meliputi sikap seperti keinginan untuk melakukan hal yang terbaik, kapasitas intelektual seperti kritis dan alasan moral, perilaku seperti jujur dan bertanggung jawab, mempertahankan prinsip-prinsip moral dalam situasi penuh ketidak adilan, kecakapan interpersonal dan emosional yang memungkinkan seorang berinteraksi secara efektif dalam berbagai keadaan, dan komitmen untuk berkontribusi dengan komunitas dan masyarakatnya. ${ }^{16}$

Berdasarkan definisi karakter di atas, karakter merupakan nila-nilai yang berhubungan dengan Tuhan yang maha esa, diri sendiri, manusia, situasi, dan lingkungan. Karakter seseorang terbentuk karena kebiasaan yang dilakukan, sikap yang diambil menanggapi keadaan. Pendidikan karakter sebagai suatu penanaman nilai-nilai karakter kepada peserta didik meliputi pengetahuan, kesadaran, baik terhadap Tuhan yang maha esa, sehingga menjadi insan kamil.

Parwez menurunkan beberapa defenisi pendidikan karakter. Defenisi tersebut dijabarkan sebagai berikut:

a. Molaritas adalah karakter. Karakter merupakan sesuatu yang terukir dalam diri seseorang. Karakter merupakan kekuatan batin. Pelanggaran susila (amoralitas) juga merupakan karakter, tetapi untuk menjadi bermoral dan tidak bermoral adalah sesuatu yang ambigu.

b. Karakter adalah manisfestasi kebenaran, dan kebenaran adalah penyesuaian kemunculan pada realitas.

c. Karakter adalah mengadopsi kebaikan dan kebaikan adalah gerakan menuju suatu tempat kediaman. Kejahatan adalah perasaan gelisah yang tiada berujung dari potensialitas manusia tanpa sesuatu yang dapat dicapai, jika tidak mengambil arah namun tetap juga terjebak dalam ketidak tahuan, dan akhirnya semua sirna.

d. Karakter adalah memiliki kekuatan terhadap diri sendiri; karakter adalah kemenangan dari penghambaan terhadap diri sendiri.

e. Karakter adalah sikap manusia terhadap lingkungannya yang diekspresikan dalam tindakan. ${ }^{17}$

Definisi tersebut dapat dikatakan bahwa karakter adalah moralitas kebenaran, sikap seseorang ditunjukkan kepada orang lain melalui tindakan baik dan buruknya tergambar dalam moralitas yang dimiliki. Pendidikan karakter adalah upaya sengaja membantu

\footnotetext{
${ }^{15}$ Lorens Bagus, Kamus Filsafat, h. 392.

16 Zubaedi, Desain pendidikan Karakter: Konsepsi dan Aplikasinya dalam Lembaga pendidikan, h. 9.

17 Muhammad Yaumi, Pindidikan Karakter Landasan, Pilar \& Implementasi (Cet. I; Jakarta: Prenadamedia Group, 2014), h. 7.
} 
orang peduli terhadap dasar nilai-nilai etika. Karakter religius atau sikap dan prilaku religius merupakan sikap dan prilaku yang dekat dengan hal-hal spiritual. Seseorang disebut religius ketika ia merasa perlu dan berusaha mendekatkan dirinya dengan Tuhan (sebagai Penciptanya), dan patuh melaksanakan ajaran agama yang dianutnya. ${ }^{18}$

Berdasarkan definisi-definisi tersebut dapat disimpulkan bahwa pembentukan karakter religius merupakan suatu proses bimbingan oleh guru, alam ataupun lingkungan sekitarnya untuk memperoleh sikap atau tabiat yang patuh terhadap ajaran agama yang dianutnya.

Upaya menumbuhkan karakter religius tentu tidaklah mudah. Hal ini memerlukan kerja sama yang baik antara guru agama dengan tim pengajar mata pelajaran lain, dan pihak sekolah yang terkait. Selain itu membiasakan peserta didik melakukan kegiatan keagamaan dengan aktif pada kegiatan ekstra kurikuler yang bersifat religius. Karakter religius ini akan menuntun peserta didik bertindak sesuai moral dan etika.

Kegiatan religius yang dapat diajarkan kepada peserta didik di sekolah dapat dijadikan sebagai pembiasaan, diantaranya;

a. Berdoa atau bersyukur.

Berdoa merupakan ucapan syukur secara langsung kepada Tuhan. Ungkapan syukur dapat pula diwujudkan dalam relasi atau hubungan seseorang dengan sesama, yaitu dengan membangun persaudaraan tanpa dibatasi oleh suku, ras, dan golongan. Kerelaan seorang peserta didik memberikan ucapan selamat hari raya kepada teman tidak seiman merupakan bentuk penghorematan kepada sesama yang dapat dikembangkan sejak anak usia dasar. Ungkapan syukur terhadap lingkungan alam misalnya menyiram tanaman, membuang sampah pada tempatnya, dan memperlakukan binatang dengan baik.

b. Melaksanakan kegiatan dimushalla atau mesjid.

Berbagai kegiatan di mushalla dapat dijadikan pembiasaan untuk menumbuhkan perilaku religius. Kegiatan tersebut di antaranya shalat dzuhur berjamaah setiap hari, sebagai tempat untuk mengikuti kegiatan belajar baca tulis al-Quran, dan shalat jumat berjamaah. Pesan moral yang didapat dalam kegiatan tersebut dapat menjadi bekal bagi peserta didik di sekolah untuk berprilaku sesui moral dan etika.

c. Merayakan hari raya keagamaan sesuai dengan agamanya.

Untuk yang beragama Islam, momen-momen hari raya Idul Adha, Isra' Mi'raj, dan Idul Fitri dapat dijadikan sarana untuk meningkatkan iman dan takwa. Begitu juga bagi yang beragama Nasrani, perayaan Natal dan Paskah akan dapat dijadikan momen penting untuk menuntun peserta didk agar bermoral dan beretika.

d. Mengadakan kegiatan keagamaan sesuai dengan agamanya.

Sekolah juga dapat menyelenggarakan kegiatan keagamaan lainnya di waktu yang sama untuk agama yang berbeda, misalnya kegiatan pesantren Ramadhan bagi yang

${ }^{18}$ Syamsul Kurniawan, Pendidikan Karakter: Konsepsi \& Implementasinya Secara Terpadu di Lingkungan Keluarga, Sekolah, Perguruan Tinggi, dan Masyarakat, h. 127. 
beragam Islam dan kegiatan rohani lain bagi yang beragama Nasrani maupun Hindu.

Kegiatan-kegiatan tersebut, diharapkan akan tumbuh toleransi beragama, saling menghargai perbedaan sehingga dapat terjalin hubungan yang harmonis, dalam perbedaan. Mereka akan merasa bahwa semua adalah saudara yang perlu dihormati, dihargai, dikasihi, dan disayangi seperti keluarga sendiri.

\section{METODE PENELITIAN}

Jenis Penelitian ini adalah ex post facto dengan menggunakan pendekatan kuantitatif. Populasi berjumlah 944, sampel 94 peserta didik, dengan teknik sampel Proportionate Stratified Random Sampling. Instrumen penelitian adalah angket, dokumentasi, dan observasi, data yang diperoleh dianalisis dengan menggunakan statistik deskriptif dan inferensial, yaitu teknik analisis regresi linear sederhana dan berganda.

\section{HASIL DAN PEMBAHASAN}

\section{Realitas Aktivitas Belajar Peserta Didik SMA Negeri 7 Makassar}

Berdasarkan penelitian yang telah dilakukan terhadap peserta didik di SMA Negeri 7 Makassar yang berjumlah 94 orang peserta didik yang menjadi sampel, maka peneliti dapat mengumpulkan data melalui angket yang telah diisi oleh peserta didik sendiri, yang kemudian hasil pengskoran disetiap item di analisis dengan menggunakan SPSS dengan menggunakan uji statistik deskriptif. Uji tersebut menggambakan rata-rata aktivitas belajar peserta didik, nilai terendah aktivitas peserta didik, dan nilai tertinggi aktivitas belaja peserta didik, juga menggambarkan nilai median dan nilai modus aktivitas belajar peserta didik. Hal ini sangat penting diketahui agar tergambar seacara umum tentang aktivitas belajar peserta didik SMA Negeri 7 Makassar.

Table 1. Statistik Deskriptif Aktivitas Belaar

\begin{tabular}{|l|c|}
\hline \multicolumn{2}{|c|}{ Statistik } \\
\hline Subjek & 94 \\
\hline Rata-rata & 68.98 \\
\hline Median & 67.50 \\
\hline Modus & 65.00 \\
\hline Standar deviasi & 7,16 \\
\hline Varians & 51.38 \\
\hline Rentang & 34.00 \\
\hline Nilai terendah & 48 \\
\hline Nilai tertinggi & 82 \\
\hline Jumlah total & 6485.00 \\
\hline
\end{tabular}

Pada tabel 1 di atas terlihat bahwa rata-rata aktivitas belajar peserta didik SMA Negeri 7 Makassar yaitu 68,98 dengan nilai ideal yang mungkin dicapai adalah 100. Nilai terendah untuk aktivitas peserta didik adalah 48 dan nilai tertinggi 82. Nilai rentang peserta didik adalah 34,00. Nilai varians adalah 51,38. Standar deviasi aktivitas peserta didik adalah 7,16. Nilai modus adalah 65,00. Jumlah total nilai aktivitas peserta didik 
adalah 6485,00. Dan jumlah peserta didik sebanyak 94 orang.

Hal yang penting juga diketahui adalah distribusi nilai aktivitas belajar peserta didik yang dikelompokkan dalam kategori tinggi sekali, tinggi, cukup, rendah, dan rendah sekali. Hal ini juga penting untuk mengetahui persentase aktivitas belajar peserta didik SMA Negeri 7 Makassar. Untuk lebih jelasnya dapat dilihat pada tabel berikut.

Tabel 2. Distribusi frekuensi dan kategorisasi nilai aktivitas belajar

\begin{tabular}{|c|c|c|c|c|}
\hline No & Interval Nilai & Kategori & Frekuensi & Persentase (\%) \\
\hline 1 & $48-55$ & Rendah & 1 & 1,06 \\
\hline 2 & $56-64$ & Sedang & 19 & 20,21 \\
\hline 3 & $65-72$ & Tinggi & 47 & 50,00 \\
\hline 4 & $73-100$ & Sangat Tinggi & 27 & 28,73 \\
\hline \multicolumn{3}{|c|}{ Jumlah } & 94 & 100,00 \\
\hline
\end{tabular}

Tabel 2 di atas menunjukkan bahwa distribusi nilai aktivitas belajar peserta didik hanya terpusat pada kategori sangat tinggi, tinggi, sedang dan rendah. Jumlah peserta didik yang berada pada kategori aktivitas sangat tinggi adalah 27 orang (28,73\%), kategori tinggi adalah 47 orang (50\%), kategori sedang adalah 19 orang (20,21\%) dan peserta didik yang berada pada kategori rendah adalah sebanyak 1 orang $(1,06 \%)$.

\section{Realitas Motivasi Belajar Peserta Didik SMA Negeri 7 Makassar}

Penilaian motivasi belajar peserta didik diukur dengan menggunakan angket motivasi, yang kemudian peserta didik diminta memberikan jawaban dan setiap jawaban diberikan skor.

Tabel 3. Hasil analisis angket motivasi belajar peserta didik

\begin{tabular}{|l|c|}
\hline \multicolumn{2}{|c|}{ Statistik } \\
\hline Subjek & 94 \\
\hline Rata-rata & 77.00 \\
\hline Median & 77.00 \\
\hline Modus & 65.00 \\
\hline Standar deviasi & 78.00 \\
\hline Varians & 61.46 \\
\hline Rentang & 37.00 \\
\hline Nilai terendah & 56.00 \\
\hline Nilai tertinggi & 93.00 \\
\hline Jumlah total & 7238.00 \\
\hline
\end{tabular}

Pada tabel 3 di atas terlihat bahwa rata-rata motivasi belajar peserta didik yaitu 77,00 dengan nilai ideal yang mungkin dicapai adalah 100. Nilai terendah untuk motivasi peserta didik adalah 56,00 dan nilai tertinggi 93,00. Nilai rentang peserta didik adalah 37,00. Nilai varians adalah 61,46 . Standar deviasi motivasi peserta didik adalah 7,83. Nilai modus adalah 78,00. Jumlah total nilai motivasi peserta didik adalah 7238,00. Dan 
jumlah peserta didik sebanyak 94 orang.

Distribusi nilai motivasi belajar peserta didik SMA Negeri 7 Makassar setelah dikelompokkan dalam kategori tinggi sekali, tinggi, cukup, rendah, dan rendah sekali.

Tabel 4. Distribusi frekuensi dan kategorisasi nilai motivasi belajar

\begin{tabular}{|c|c|c|c|c|}
\hline No & Interval Nilai & Kategori & Frekuensi & Persentase (\%) \\
\hline 1 & $56-64$ & Rendah & 1 & 1,06 \\
\hline 2 & $65-73$ & Sedang & 26 & 27,66 \\
\hline 3 & $74-82$ & Tinggi & 43 & 45,75 \\
\hline 4 & $83-100$ & Sangat Tinggi & 24 & 25,53 \\
\hline \multicolumn{2}{|r|}{ Jumlah } & $\mathbf{9 4}$ & $\mathbf{1 0 0 , 0 0}$ \\
\hline
\end{tabular}

Tabel 4, di atas menunjukkan bahwa distribusi nilai motivasi belajar peserta didik hanya terpusat pada kategori tinggi sekali, tinggi, sedang, dan rendah. Jumlah peserta didik yang berada pada kategori motivasi sangat tinggi adalah 24 orang (25,53\%), kategori tinggi adalah 43 orang (45,75\%), kategori sedang adalah 26 orang (27,66\%), dan yang yang termasuk kategori rendah adalah 1 orang $(1,06 \%)$.

\section{Pembentukan Karakter Religius Peserta Didik SMA Negeri 7 Makassar}

Penilaian pembentukan karakter religius peserta didik diketahui dan diukur dengan menggunakan pedoman obervasi. Hasil perolehan data observasi tentang karakter relelgius peserta didik SMA Negeri 7 Makassar dapat dilihat melalui tabel berikut:

Tabel 5. Hasil analisis observasi pembentukan karakter religius

\begin{tabular}{|l|c|}
\hline & Statistik \\
\hline Subjek & 94 \\
\hline Rata-rata & 78.39 \\
\hline Median & 78.50 \\
\hline Modus & 80.00 \\
\hline Standar deviasi & 7.04 \\
\hline Varians & 49.69 \\
\hline Rentang & 30.00 \\
\hline Nilai terendah & 62.00 \\
\hline Nilai tertinggi & 92.00 \\
\hline Jumlah total & 7369.00 \\
\hline
\end{tabular}

Pada tabel 5, di atas terlihat bahwa rata-rata karakter religius peserta didik yaitu 78.39 dengan nilai ideal yang mungkin dicapai adalah 100. Nilai terendah untuk karakter religius peserta didik adalah 62,00 dan nilai tertinggi 92,00. Nilai rentang peserta didik adalah 30,00. Nilai varians adalah 49,69. Standar deviasi karakter religius peserta didik adalah 7,07. Nilai modus adalah 80,00. Jumlah total adalah 7369,00.

Distribusi nilai karakter religius peserta didik setelah dikelompokkan dalam kategori tinggi sekali, tinggi, cukup, rendah, dan rendah sekali dapat dilihat pada tabel 6. 
Tabel 6. Distribusi frekuensi dan kategorisasi nilai karakter religius

\begin{tabular}{|c|c|c|c|c|}
\hline No & Interval Nilai & Kategori & Frekuensi & Persentase (\%) \\
\hline 1 & $62-68$ & Rendah & 3 & 3,19 \\
\hline 2 & $69-75$ & Sedang & 33 & 35,10 \\
\hline 3 & $76-82$ & Tinggi & 46 & 48,94 \\
\hline 4 & $83-100$ & Sangat Tinggi & 12 & 12,77 \\
\hline \multicolumn{2}{|r|}{ Jumlah } & $\mathbf{9 4}$ & $\mathbf{1 0 0}$ \\
\hline
\end{tabular}

Tabel 6. di atas menunjukkan bahwa distribusi nilai pembentukan karakter religius peserta didik terpusat pada kategori tinggi sekali, tinggi, sedang dan rendah. Jumlah peserta didik yang berada pada kategori nilai karakter religius peserta didik rendah adalah 3 orang $(3,19 \%)$, kategori sedang adalah 33 orang (35,10\%), kategori tinggi adalah 46 orang $(48,94 \%)$ dan kategori tinggi sekali adalah 12 orang $(12,77 \%)$.

\section{Pengaruh Aktivitas Belajar terhadap Pembentukan Karakter Religius Peserta Didik di SMA Negeri 7 Makassar}

Analisis statistik inferensial dilakukan untuk menguji hipotesis penelitian atau untuk mengetahui ada pengaruh aktivitas belajar peserta didik terhadap pembentukan karakter religius peserta didik. Analisis ini menggunakan teknik analisis kovarian (anacova) dengan taraf signifikansi $\alpha=0,05$. Syarat yang harus dipenuhi untuk pengujian hipotesis ini adalah data yang diperoleh harus berdistribusi normal. Oleh karena itu sebelumnya diadakan uji normalitas.

\section{a. Uji Normalitas}

Uji normalitas merupakan salah satu bagian dari uji persyaratan analisis data atau uji asumsi klasik, artinya sebelum kita lakukan analisis yang sesungguhnya, data peneliti tersebut harus diuji kenormalan distribusinya. Jika nilai signifikansi lebih besar dari 0,05 maka data tersebut berdistribusi normal. Sebaliknya jika nilai signifikansi lebih kecil dari 0,05, maka data tersebut tidak berdistribusi normal.

Tabel 7. Hasil uji normalitas data aktivitas belajar peserta didik

\begin{tabular}{|c|c|}
\hline Variabel X1 & Nilai Signifikan \\
\hline Aktivitas Peserta Didik & 0,898 \\
\hline
\end{tabular}

Berdasarkan output di atas, diketahui bahwa nilai signifikansi sebesar 0,898 lebih besar dari 0,05, sehingga disimpulkan bahwa data yang diuji berdistribusi normal.

b. Uji Hipotesis

Uji hipotesis: uji parsial atau disebut juga uji t dalam analisis regresi linear berganda bertujuan untuk mengetahui apakah variabel bebas (X) secara parsial (sendirisendiri/masing-masing variabel) berpengaruh signifikan terhadap variabel terikat (Y). 
Tabel 8. Hasil uji t dari data aktivitas belajar

\begin{tabular}{|c|c|c|}
\hline Variabel X1 & Nilai T & Nilai Signifikan \\
\hline Aktivitas Peserta Didik & 10,233 & 0,000 \\
\hline
\end{tabular}

Berdasarkan hasil output SPSS di atas kita dapat melihat dimana nilai t hitung variabel X1 lebih besar dari pada nilai t tabel $(10,233>1,664)$ dengan tingkat signifikan dibawah 0,05 yaitu 0,000. Berdasarkan cara pengambilan keputusan uji parsial dalam analisis regresi dapat disimpulkan bahwa variabel aktivitas belajar peserta didik berpengaruh signifikan terhadap pembentukan karakter religius peserta didik. Sebagai mana kita pahami bahwa jika nilai t dari variabel aktivitas peserta didik sebagai variabel bebas lebih besar daripada nilai t tabel maka variabel aktivitas berpengaruh secara signifikan terhadap karakter religius peserta didik sebagai variabel terikat.

\section{Pengaruh Motivasi Belajar terhadap Pembentukan Karakter Religius Peserta Didik di SMA Negeri 7 Makassar}

Analisis statistik inferensial dilakukan untuk menguji hipotesis penelitian atau untuk mengetahui ada pengaruh motivasi terhadap pembentukan karakter religius peserta didik. Analisis ini menggunakan teknik analisis kovarian (anacova) dengan taraf signifikansi $\alpha=0,05$. Syarat yang harus dipenuhi untuk pengujian hipotesis ini adalah data yang diperoleh harus berdistribusi normal. Oleh karena itu sebelumnya diadakan uji normalitas.

\section{a. Uji Normalitas}

Uji normalitas merupakan salah satu bagian dari uji persyaratan analisis data atau uji asumsi klasik, artinya sebelum kita lakukan analisis yang sesungguhnya, data peneliti tersebut harus diuji kenormalan distribusinya. Jika nilai signifikansi lebih besar dari 0,05 maka data tersebut berdistribusi normal. Sebaliknya jika nilai signifikansi lebih kecil dari 0,05 , maka data tersebut tidak berdistribusi normal. Untuk lebih jelasnya dapat dilihat pada table 9 berikut:

Tabel 9. Hasil uji normalitas data motivasi belajar

\begin{tabular}{|c|c|}
\hline Variabel X2 & Nilai Signifikan \\
\hline Motivasi Peserta Didik & 0,263 \\
\hline
\end{tabular}

Berdasarkan output di atas, diketahui bahwa nilai signifikansi sebesar 0,263 lebih besar dari 0,05, sehingga disimpulkan bahwa data yang diuji berdistribusi normal.

b. Uji Hipotesis

Uji hipotesis: uji parsial atau disebut juga uji t dalam analisis regresi linear berganda bertujuan untuk mengetahui apakah variabel bebas (X) secara parsial (sendirisendiri/masing-masing variabel) berpengaruh signifikan terhadap variabel terikat (Y). 
Tabel 10. Hasil uji t dari data motivasi belajar

\begin{tabular}{|c|c|c|}
\hline Variabel X2 & Nilai T & Nilai Signifikan \\
\hline Motivasi Peserta Didik & 21.776 & 0,000 \\
\hline
\end{tabular}

Berdasarkan hasil output SPSS di atas kita dapat melihat dimana nilai t hitung variabel X2 lebih besar dari pada nilai t tabel $(21,776>1,664)$ dengan tingkat signifikan di bawah 0,05 yaitu 0,000. Berdasarkan cara pengambilan keputusan uji parsial dalam analisis regresi dapat disimpulkan bahwa variabel motivasi belajar peserta didik berpengaruh signifikan terhadap pembentukan karakter religius peserta didik. Sebagai mana kita pahami bahwa jika nilai t dari variabel motivasi peserta didik sebagai variabel bebas lebih besar daripada nilai t tabel maka variabel motivasi berpengaruh secara signifikan terhadap karakter religius peserta didik sebagai variabel terikat.

\section{Pengaruh Aktivitas Belajar Secara Bersama-Sama dengan Motivasi Belajar terhadap Pembentukan Karakter Religius Peserta Didik di SMA Negeri 7 Makassar.}

Pada bagian ini menggunakan uji $\mathrm{F}$ simultan hal ini digunakan untuk mengetahui pengaruh variabel bebas secara bersama-sama (simultan) terhadap variabel terikat. Berikut ini adalah hasil analisis anova yeng menunjukkan bagaimana pengaruh aktivitas peserta didik dan motivasi peserta didik secara bersama-sama terhadap pembentukan karakter religius peserta didik.

Tabel 11. Hasil uji F simultan dari data aktivitas dan motivasi belajar terhadap pembentukan karakter religius

\begin{tabular}{|c|c|c|}
\hline \multicolumn{3}{|c|}{ Uji F Simultan (Anova) } \\
\hline Variabel & Nilai T & Nilai Signifikan \\
\hline $\mathrm{X} 1+\mathrm{X} 2=\mathrm{Y} 1$ & 268.920 & 0,000 \\
\hline
\end{tabular}

Berdasarkan data di atas, didapatkan nilai signifikan F sebesar 0,000 $(\mathrm{P}<0,05)$ maka dapat disimpulkan bahwa hipotesis diterima, artinya variabel aktivitas belajar dan motivasi belajar peserta didik berpengaruh secara signifikan secara bersama-sama terhadap pembentukan karakter religius peserta didik. Sebagaimana kita pahami bahwa jika nilai t dari variabel bebas yaitu aktivitas dan motivasi belajar peserta didik lebih besar daripada nilai signifikan maka hipotesis diterima. Artinya variabel X1 dan X2 berpengaruh secara bersama-sama terhadap pembentukan karakter religius peserta didik di SMA Negeri 7 Makassar.

\section{KESIMPULAN.}

Berdasarkan hasil analisis data dan pembahasan hasil penelitian maka dapat disimpulkan beberapa hal sebagai berikut:

1. Berdasarkan hasil analisis penelitian yang diperoleh menunjukkan bahwa skor aktivitas belajar peserta didik di SMA Negeri 7 Makassar pada seluruh subjek 
penelitian ini termasuk dalam kategori tinggi.

2. Berdasarkan hasil analisis penelitian yang diperoleh menunjukkan bahwa skor motivasi belajar peserta didik di SMA Negeri 7 Makassar pada seluruh subjek penelitian ini termasuk dalam kategori tinggi.

3. Berdasarkan hasil analisis penelitian yang diperoleh menunjukkan bahwa skor pembentukan karakter religius peserta didik di SMA Negeri 7 Makassar pada seluruh subjek penelitian ini termasuk dalam kategori tinggi.

4. Berdasarkan data hasil uji inferensial menunjukan bahwa aktivitas belajar berpengaruh signifikan terhadap pembentukan karakter religius peserta didik di SMA Negeri 7 Makassar.

5. Berdasarkan data hasil uji inferensial menunjukan bahwa motivasi belajar berpengaruh signifikan terhadap pembentukan karakter religius peserta didik di SMA Negeri 7 Makassar.

6. Berdasarkan data hasil uji inferensial menunjukan bahwa aktivitas belajar dan motivasi belajar secara bersama-sama berpengaruh signifikan terhadap pembentukan karakter religius peserta didik di SMA Negeri 7 Makassar.

\section{DAFTAR PUSTAKA}

A.M. Sardiman, Inrteraksi dan Motivasi Belajar Mengajar, Ed.I. Cet. XXI; Jakarta: RajaGrafindo Persada, 2010.

A.M. Sardiman, Inrteraksi Motivasi Belajar Mengajar, Ed.I. Cet. XXIII; Jakarta: Raja Grafindo Persada, 2016.

Arikunto, Suharsimi. Prosedur Penelitian Suatu Pendekatan Praktik, Edisi Revisi. Cet. XIII; Jakarta: Rineka Cipta, 2006.

Arikunto, Suharsimi. Prosedur Penelitian; Suatu Pendekatan Praktik. Cet. XIV; Jakarta: Rineka Cipta, 2010.

Bagus, Lorens. Kamus Filsafat. Jakarta: Gramedia, 2005.

Hamalik Oemar, Kurikulum dan Pembelajaran. Cet. XV; Jakarta: Bumi Aksara, 2015.

Kurniawan Syamsul, Pendidikan Karakter: Konsepsi \& Implementasinya Secara Terpadu di Lingkungan Keluarga, Sekolah, Perguruan Tinggi, dan Masyarakat, h. 127.

Nata, Abuddin. Perspektif Islam Tentang Strategi Pembelajaran. Jakarta: Kencana Media Group, 2009.

Sugiyono, Metodologi Penelitian Pendidikan Pendekatan Kuantitatif, Kualitatif, dan $R \& D$, Bandung; Alfabeta, 2010.

.... Metode Penelitian Pendidikan. Cet. 16; Bandung: Alfabeta, 2013. 
Suyudi, HM. Pendidikan Dalam Perspektif Al-Qur'an: Integrasi Epistimologi Bayani, Burhani, dan Irfani. Yogyakarta: MIKRAJ, 2005.

Syah Muhibbin, Psikologi Pendidikan Dengan Pendekatan Baru, Bandung: Remaja Rosdakarya, 2014.

Undang-Undang RI No. 20 Tahun 2003, Sistem Pendidikan Nasional, Jakarta: Sinar Grafika, 2008

Yaumi, Muhammad. Pindidikan Karakter Landasan, Pilar \& Implementasi. Cet.I; Jakarta: Prenadamedia Group, 2014.

Dalyono, M. Psikologi Pendidikan Jakarta: Rineka Cipta. 2005

Paul Suparno, Reformasi Pendidikan (Yogyakarta: Kanisius, 2002), h. 13.

Nurani Soyomukti, Teori-Teori Pendidikan Yogyakarta: Ar-ruzz Media, 2010

Pius A. Partanto dan M. Dahlan al Barry, Kamus Ilmiah Populer (Surabaya: Arkola, 1994 